\title{
PROSES PEMECAHAN MASALAH MATEMATIKA SISWA SMA BERDASARKAN KECERDASAN MAJEMUK
}

\author{
Suhartini Sumadi, Teguh Yuliandri Putra, Heny Sri Astutik \\ Universitas Pendidikan Muhammadiyah Sorong, Aimas Sorong, Indonesia \\ Email: suhartini.sumadi@gmail.com
}

\begin{abstract}
Abstrak
Penelitian ini bertujuan untuk menganalisis proses pemecahan masalah matematika siswa SMA berdasarkan kecerdasan majemuk. Kecerdasan majemuk dalam penelitian dibagi menjadi tiga, yaitu kecerdasan dominan linguistik, interpersonal dan kinestetis; kecerdasan dominan musikal, logis matematis dan naturalistik; serta kecerdasan dominan eksistensial, intrapersonal dan visual. Jenis penelitian yang digunakan dalam penelitian ini adalah deskriptif eksploratif, serta pendekatan yang digunakan adalah pendekatan kualitatif dan kuantitatif. Penentuan subyek penelitian dilakukan dengan menggunakan purposive sampling berdasarkan kecerdasan majemuk, sehingga diperoleh 3 orang siswa SMA kelas X sebagai subyek penelitian. Instrumen penelitian yang digunakan adalah tes kecerdasan majemuk dan dua tes pemecahan masalah yang diadopsi dari American High School Math Exam (AHSME) Problems dan soal olimpiade sains Nasional matematika SMA tingkat Provinsi. Data yang diperoleh dianalisis dengan cara reduksi data. Hasil dari penelitian menunjukkan bahwa peserta didik dengan kecerdasan majemuk yang berbeda, memiliki cara penyelesaian yang berbeda, namun juga terdapat persamaan dalam menyelesaikan masalah.
\end{abstract}

Kata kunci: Pemecahan Masalah Matematika, Kecerdasan Majemuk, deskriptif eksploratif, Sekolah Menengah Atas

\begin{abstract}
This study aims to analyze the mathematics problem-solving process of high school students based on multiple intelligences. In research, multiple intelligence is divided into dominant linguistic intelligence, interpersonal and kinesthetic intelligence, dominant musical intelligence, logicalmathematical and naturalistic, existential, intrapersonal, and visual dominant intelligence. The type of research used in this research is descriptive exploratory, and the approach used is qualitative and quantitative approaches. Determination of research subjects was carried out using purposive sampling based on multiple intelligences, to obtain 3 high school students of class $\mathrm{X}$ as research subjects. The research instrument used was a multiple intelligence test and two problem-solving tests adopted from the American High School Math Exam (AHSME) Problems and the Provincial High School Mathematics National Science Olympiad questions. The data obtained were analyzed, utilizing data reduction. The research results show that students with multiple different intelligence bits have different ways of solving them, but there are also similarities in solving problems.
\end{abstract}

Keywords: Mathematical Problem Solving, Multiple Intelligences, Explorative Descriptive, Senior High School

\section{PENDAHULUAN}

Tujuan utama pembelajaran matematika adalah peserta didik dituntut memiliki kemampuan berpikir tingkat tinggi dan berkarakter untuk mencapai derajat pemahaman 
yang signifikan pada pembelajaran matematika. Salah satu tujuan terpentingnya adalah kemampuan memecahkan masalah (Permendikbud Nomor 21 Tahun 2016). Kemampuan memecahkan masalah pada hakikatnya merupakan suatu keterampilan dasar dalam kehidupan seseorang agar dapat menempuh kehidupannya dengan lebih baik (Sweller, 1988; Rusyida, Asikin, \& Soedjoko, 2013; Santoso, Waluyo, \& Sukestiyarno, 2013). Dalam lingkup pembelajaran matematika, pemecahan masalah merupakan indikator untuk membangun konsep dan ide-ide peserta didik pada proses pemahamannya (Arifah \& Saefudin, 2017). Namun, realita yang terjadi secara umum, kemampuan peserta didik dalam kemampuan memecahkan masalah masih sangat kurang (Putri, 2016; Aliyah, Suyitno, \& Agoestanto, 2014). Kekurangannya tersebut tampak pada proses kontruksi dalam menjelaskan masalah yang masih sangat dangkal. Hal ini menunjukkan adanya dampak berkelanjutan terhadap kemampuan matematis peserta didik.

Kesulitan yang diperoleh peserta didik dalam memecahkan masalah tidak hanya terletak pada proses perhitungan, namun lebih pada pengetahuan dalam memperjelas masalah, sehingga masalah tersebut dapat dipecahkan (Anikrohmah, Mubarokah, \& Suhartatik, 2013). Oleh karena itu, dibutuhkan strategi pemecahan masalah matematika bagi peserta didik (Anikrohmah, dkk, 2013). Selain memperhatikan strategi pemecahan masalah, perlu diperhatikan metakognisi peserta didik (Nurasyiyah, 2014). Metakognisi bermanfaat dalam membangun kesadaran peserta didik terhadap pengetahuan yang dimilikinya dalam pemecahan masalah (Anggo, 2014).

Proses strategi pemecahan masalah yang melibatkan matekognisi peserta didik tidak terlepas dari karakter kecerdasan peserta didik (Setyadi, 2018). Setiap peserta didik memiliki keunikan masing-masing dalam hal karakter kecerdasannya. Hal ini, dapat dipahami bahwa setiap peserta didik memiliki kecerdasan beragam (majemuk) yang berbeda satu sama lainnya, sesuai dengan pola karakter kecerdasan pribadinya. Kurniawan (2014) menyatakan bahwa peserta didik dapat memiliki beberapa kecerdasan bahkan semua kecerdasan. Hal yang dimaksudkan dari pandangan tersebut adalah pola kecerdasan majemuk seseorang sangat beragam, sehingga (Gardner, 2003) mengklasifikasikannya kedalam tujuh jenis kecerdasan diantaranya kecerdasan musical, kinestetik, logika matematika, linguistik, spasial, interpersonal, dan intrapersonal. Lebih lanjut, McKenzie (2005) menambahkan kecerdasan eksistensial sebagai pelengkap dari tujuh kecerdasan yang disampaikan oleh Gardner. Hal inilah yang sangat penting untuk 
diketahui oleh guru, terlebih bagi guru matematika

Dalam penelitian terdahulu yang relevan terkait dengan pandangan para ahli di atas, menegaskan bahwa guru matematika sebaiknya mampu menyusun perangkat pembelajaran matematika dalam proses pembelajaran yang melibatkan kecerdasan majemuk peserta didik dalam upaya gaya belajar matematis semua peserta didik. (Wicaksono, dkk. 2014). Oleh karena itu, penelitian ini bertujuan untuk melihat bagaimana proses pemecahan masalah matematika peserta didik berdasarkan kecerdasan majemuk yang dimilikinya.

\section{METODE PENELITIAN}

Jenis penelitian yang digunakan dalam penelitian ini adalah deskriptif eksploratif, serta pendekatan yang digunakan adalah pendekatan kualitatif dan kuantitatif. Subjek dalam penelitian ini adalah tiga siswa kelas X SMA yang memiliki kecerdasan majemuk dengan minimal tiga kecerdasan yang dominan. Selanjutnya, subjek ditentukan dengan menggunakan metode purposive sampling, yakni teknik pengambilan sampel dengan pertimbangan tertentu yaitu dengan cara peserta didik mengisi tes kecerdasan majemuk.

Instrumen penelitian yang digunakan dalam penelitian ini, yaitu tes kecerdasan majemuk untuk melihat kecerdasan majemuk peserta didik yang terdiri dari sembilan kecerdasan dan disajikan dalam bentuk pernyataan sederhana yang dikembangkan oleh Yaumi \& Ibrahim (2013). Selanjutnya, soal tes pemecahan masalah untuk mengetahui proses peserta didik dalam memecahkan masalah. Soal tes pemecahan masalah yang digunakan pada penelitian ini berjumlah dua soal, yang diadaptasi dari American High School Math Exam (AHSME) Problems dan soal olimpiade sains Nasional matematika SMA tingkat Provinsi (Muslihun \& Hildayani, 2015). Hal ini dikarenakan proses penyelesaian masalah pada soal-soal tersebut menggunakan materi-materi yang sudah dipelajari oleh subjek. Terakhir, wawancara tidak terstruktur terkait penyelesaian masalah yang disesuaikan dengan indikator penelitian yang telah mencakup cara pemecahan masalah menurut Polya. Adapun tahapan pemecahan masalah Polya (1973), yaitu tahap pemahaman masalah, penyususnan rencana, melaksanakan rencana, dan memeriksa kembali.

Data yang diperoleh dalam penelitian ini dianalisis dengan cara mereduksi, penyajian data dan penarikan kesimpulan. Pada bagian ini, cara mereduksi data dilakukan 
dengan cara memilah data yang diperoleh dan dikelompokkan ke dalam tiga objek penelitian yaitu kelas data dominan kecerdasan (peserta didik dengan kecerdasan dominan linguistik, interpersonal dan kinestetis), kecerdasan dominan musikal, logis matematis dan naturalistic, dan kecerdasan dominan eksistensial, intrapersonal dan visual. Setelah data dikelompokkan sesuai kelas data masing-masing, barulah data disajikan dengan melihat dan mengkonstruksi data dari proses pemecahan masalah tahap Polya dan ditarik sebuah simpulan akhir.

\section{HASIL DAN PEMBAHASAN}

Hasil tes pemecahan masalah berdasarkan tiga kecerdasan yang paling dominan dapat dipaparkan sebagai berikut.

\section{Kecerdasan musical, logis matematis, dan naturalistik}

\section{Tahap Pemahaman Masalah}

Tahap ini, peserta didik mampu mengidentifikasikan masalah suatu soal, yaitu memahami masalah secara benar. Hal ini dapat diketahui pada Gambar 1.

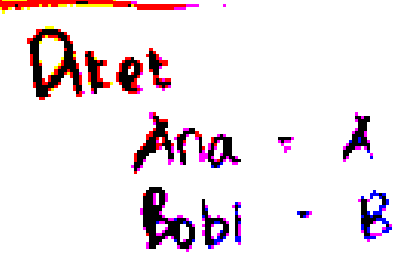

Gambar 1. Hasil tes tulis tahap pemahaman masalah oleh subjek

Berdasarkan hasil tes tulis pada tahap ini, subjek telah menyebutkan apa yang diketahui pada permasalahan, walaupun penulisannya tidak lengkap. Subjek hanya menuliskan pemisalan dari nama-nama yang terdapat pada permasalahan, yaitu Ana = A dan Bobi $=$ B, sedangkan yang dipermasalahkan adalah harga pada label. Sedangkan pada permasalahan kedua, subjek tidak menuliskan apa yang diketahui. Hal ini dikarenakan subjek merasa malas untuk menuliskan apa yang telah pasti diketahuinya.

Walaupun penulisan terhadap apa yang diketahui subjek pada permasalah tidak disebutkan secara keseluruhan, namun dari hasil wawancara menunjukkan bahwa siswa telah melalui tahap pemahaman masalah. Lebih jelasnya, dijabarkan hasil wawancara tentang pemahaman subjek pada kedua soal sebagai berikut: 
Permasalahan pertama

\begin{tabular}{|c|c|}
\hline Peneliti & : “apa yang kamulakukan saat soal diberikan?” \\
\hline Siswa & : "saya membaca soal bu" \\
\hline Peneliti & : "soalnya kamu baca untuk apa?" \\
\hline Siswa & $\begin{array}{l}\text { "saya membaca soal bu, supaya bisa tahu cara } \\
\text { penyelesaiannya dengan mencoba memahami maksud dari } \\
\text { soal." }\end{array}$ \\
\hline Peneliti & : “apa yang kamu pahami dari soal?” \\
\hline Siswa & $\begin{array}{l}\text { : "upah Ana dan Bobi sama dan harga jual barang Ana lebih } \\
\text { besar dari harga jual barang Bobi bu." }\end{array}$ \\
\hline Peneliti & $\begin{array}{l}\text { : "mengapa kamu mengatakan harga jual barang Ana lebih } \\
\text { besar dari harga jual barang Bobi?"” }\end{array}$ \\
\hline Siswa & $\begin{array}{l}\text { "ya karena pada soal tertulis bahwa barang yang dijual Ana } \\
\text { Rp 15.000,00 lebih rendah dari harga label, dan harga jual } \\
\text { barang Bobi Rp 25.000,00 lebih rendah daripada harga label. }\end{array}$ \\
\hline
\end{tabular}

Permasalahan kedua

Siswa : "Pak Anto menjual dua mobil dan mendapatkan keuntungan 20\% mobil pertama dan kerugian 10\% dari mobil kedua. Harga jualnya sama, tapi tidak diketahui berapa harga jualnya?”

Hasil wawancara dari kedua permasalahan tersebut menyatakan bahwa siswa telah memahami masalah secara benar, walaupun tidak dituliskan dengan jelas. Subjek dapat menjelaskan apa telah dipahami dengan benar, seperti pada permasalahan pertama, saat subjek menjelaskan apa yang dipahami pada permasalahan tersebut, kemudian peneliti memberikan pertanyaan tentang pemahaman yang dijelaskan, subjek dapat menjawab dengan tepat pertanyaan tersebut. Berdasarkan hasil wawancara dan hasil tes tulis tersebut, maka subjek dengan kecerdasan dominan musikal, logis matematis dan naturalistik memahami masalahdengan cara menuliskan apa yang diketahui, walaupun penulisannya tidak lengkap. Subjek juga menyebutkan hal-hal yang diketahui dan ditanya yang terdapat pada wawancara tersebut.

\section{Tahap Penyusunan Rencana}

Tahap ini menunjukkan bahwa siswa mampu merencanakan penyelesaian masalahnya dengan menyusun dan menyatakan kembali permasalahan dengan menggunakan penalaran, variabel dan persamaan, menggunakan rumus atau sifat-sifat bilangan, mencoba menyederhanakan permasalahan dan menggunakan informasi yang 
diketahui untuk mengembangkan informasi baru.

Hasil penelitian menunjukkan bahwa subjek telah melalui tahap perencanaan penyelesaian. Hal ini diketahui dari wawancara sebagai berikut.

\section{Permasalahan pertama}

Peneliti : "bagaimana solusi untuk menyelesaikan masalah ini?"

Siswa : "saya misalkan x dengan harga pada label. Untuk mencari nilai $x$, pertama-tama saya membuat persamaan upah Ani sama dengan upah Bobi, yaitu persen upahnya dikali dengan harga jual. Kemudian untuk persamaan selanjutnya saya membuat persamaan harga jual dikurangi dengan $R p$ 15.000,00 dan Rp 25.000,00. Setelah itu, saya masukkan persamaan yang sudah sederhana ke dalam persamaan kedua. Hasilnya adalah Rp 40.000,00.”

\section{Permasalahan kedua}

$\begin{array}{lll}\text { Peneliti } & : & \text { "apa yang kamu pikirkan untuk menyelesaikannya?" } \\ \text { Siswa } & : & \text { "karena yang ditanyakan adalah persen keuntungan, jadi } \\ & \text { saya harus mencari harga jualnya dulu." } \\ \text { Peneliti } & : & \text { "Bagaimana caranya?" } \\ \text { Siswa } & : & \text { "karena harga jual kedua mobil sama, jadi harga jual mobil } \\ & \text { pertama sama dengan harga jual mobil kedua. Kemudian, } \\ & \text { harga jualnya sama dengan persen keuntungan atau kerugian } \\ & \text { dari harga beli ditambah dengan harga beli. Pada jawaban, } \\ & \text { saya misalkan harga beli sebagai x dan membuat persamaan, } \\ & \text { jadi saya akan mencari tahu nilai } x \text { dulu baru } \\ & \text { menyelesaikannya." }\end{array}$

Hasil wawancara tersebut jelas menunjukkan bahwa subjek telah merencakan proses pemecahan masalah sebelumnya. Subjek memahami masalah subjek pada permasalahan pertama dengan cara memisalkan harga pada label dengan variabel $\mathrm{x}$, kemudian subjek membuat dua persamaan. Subjek membuat persamaan pertama yang disederhanakan untuk disubstitusikan pada persamaan kedua yang telah diperoleh. Persamaan kedua, subjek menjelaskan solusi untuk menyelesaikan permasalahan tersebut dengan cara memisalkan harga beli sebagai x kemudian membuat persamaan. Subjek menjelaskan apa yang harus diselesaikan terlebih dahulu untuk memecahakan masalah tersebut.

Berdasarkan hasil wawancara, dapat dikatakan bahwa siswa dengan kecerdasan dominan musikal, logis matematis dan naturalistik menyusun rencanadalam 
menyelesaikan masalah dengan cara memisalkan hal yang ditanya dengan variabel dan membuat persamaan.

\section{Tahap Melaksanakan Rencana}

Tahap ini menunjukkan bahwa peserta didik mampu meyelesaikan masalah suatu soal sesuai dengan rencana. Hasil penelitian menunjukkan bahwa kedua peserta didik telah melakukan pelaksanaan perencenaan penyelesaian masalah. Hal ini dapat dilihat pada Gambar 2.

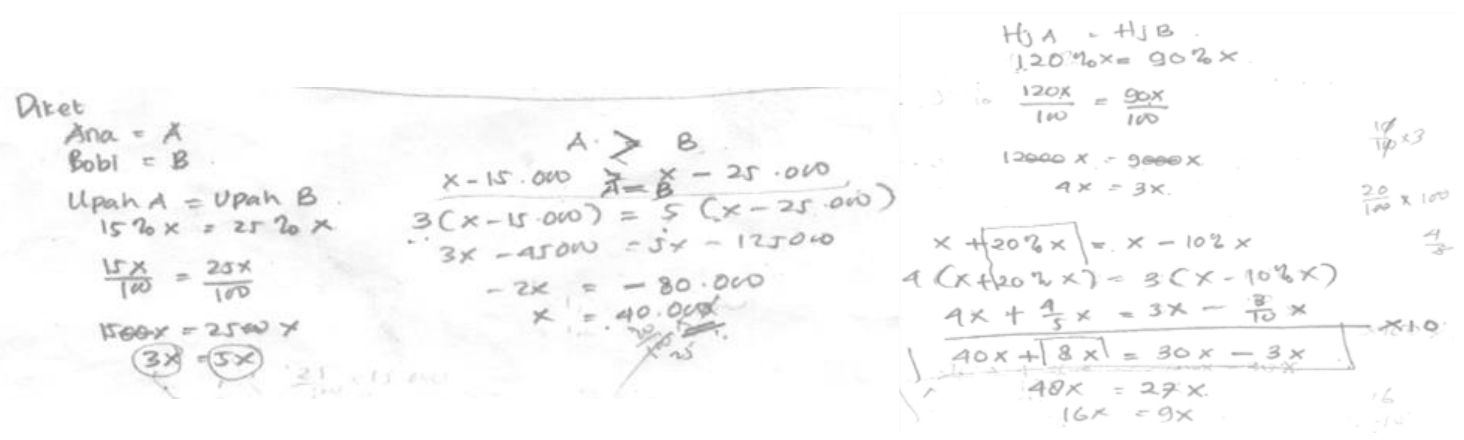

Gambar 2. Proses pemecahan masalah oleh subjek

Gambar 2 menunjukkan bahwa subjek melakukan proses pemecahan masalah sesuai dengan rencana yang dijelaskan melalui wawancara sebelumnya. Seperti pada permasalahan pertama, subjek bahwa subjek membuat dua persamaan. Persamaan pertama diperoleh dari harga jual dari persentase upah yang kemudian disederhanakan, kemudian penyederhanaan persamaan pertama disubstitusikan ke dalam persamaan kedua yang diperoleh dari harga jual yang dikurangi dengan dengan Rp 15.000,00 dan Rp 25.000,00.

Permasalahan kedua, subjek menuliskan dua persamaan. Persamaan pertama diperoleh dari persentase keuntungan \& kerugian dikali dengan harga jual, yang kemudian persamaan tersebut disederhanakan, kemudian penyederhanaan persamaan tersebut disubstitusikan ke dalam persamaan kedua.

Perencanaan penyelesaian yang telah dijelaskan subjek melalui wawancara telah sesuai dengan yang dituliskan, walaupun tidak dijelaskan secara lengkap. Selain itu, proses pemecahan masalah pada permasalahan kedua tidak diselesaikan sampai mendapatkan hasil akhir. Walaupun demikian, subjek dengan kecrdasan dominan 
musikal, logis matematis dan naturalistik melalui tahap pelaksanaan perencanaan penyelesaian masalah dengan cara memisalkan sesuatu yang tidak diketahui dengan variabel, kemudian membuat dua persamaan, persamaan pertama disederhanakan untuk disubstitusikan ke dalam persamaaan kedua.

\section{Tahap Memeriksa Kembali}

Tahap ini ditunjukkan dengan siswa mengecek kembali hasil yang diperoleh, dengan cara mengecek semua hal yang telah dilakukan apakah semua yang telah dilakukan dalam proses pemecahan masalah masuk akal untuk masalah pada soal tersebut atau tidak. Hasil penelitian untuk tahap ini dapat diketahui dari hasil wawancara berikut.

\section{Permasalahan pertama}

$\begin{array}{lll}\text { Peneliti } & : & \text { "bagaimana jawabannya, yakin gak dengan jawabannya?" } \\ \text { Siswa } & : & \text { "saya yakin benar" } \\ \text { Peneliti } & : & \text { "mengapa?" } \\ \text { Siswa } & : & \text { "karena sudah saya buktikan., } \\ \text { Peneliti } & : & \text { "bagaimana anda membuktikannya?" } \\ \text { Siswa } & : & \text { "saya kurangi harga label dengan Rp 15.000,00 dan Rp } \\ & \text { 25.000,00 dan diperoleh harga jualnya, kemudian harga jual } \\ & \text { dikali dengan persentase upah yang diperoleh, sehingga } \\ & \text { diperoleh hasil yang sama, yaitu Rp 3.750,00." }\end{array}$

Permasalahan kedua

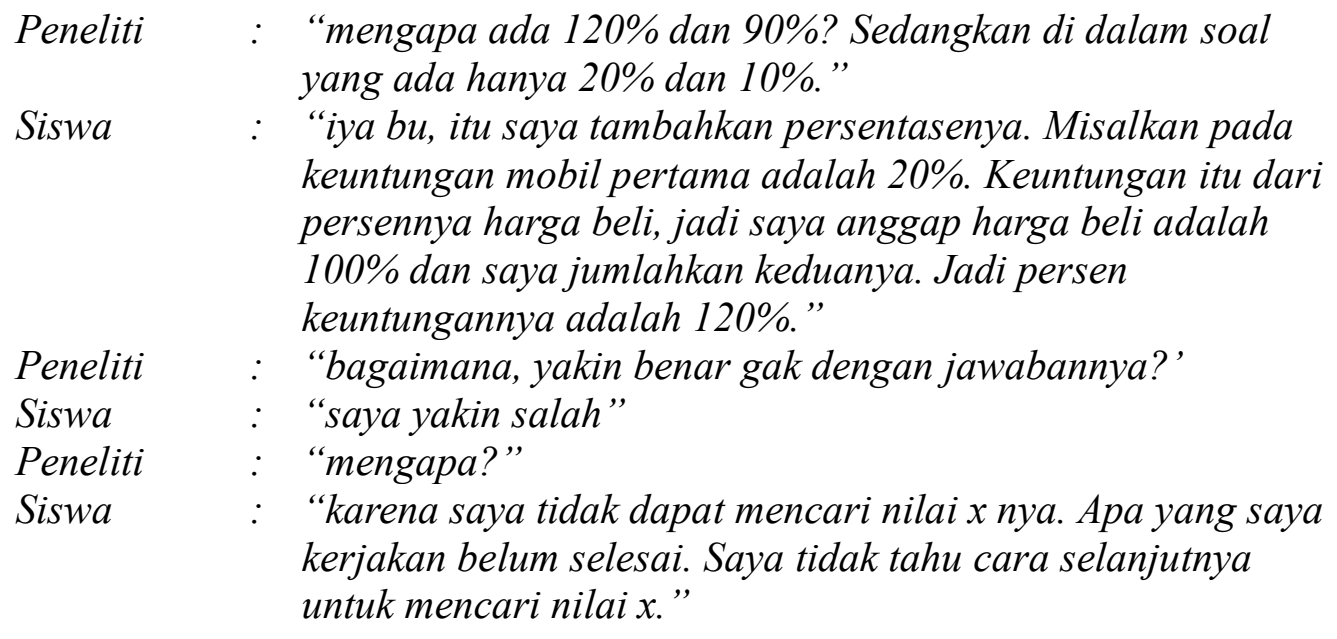

Hasil wawancara tersebut menunjukkan bahwa subjek telah dapat mengetahui alasan dari apa yang ditulis, serta terdapat keyakinan terhadap jawabannya dan dapat dibuktikan. Subjek dapat menjelaskan tentang apa saja yang ditulis. Permasalahan 
pertama, subjek meyakini bahwa proses penyelesaian masalahnya benar sampai akhir. Subjek NS yakin hasil akhirnya telah dibuktikan dengan mengurangi harga label dengan Rp 15.000,00 dan Rp 25.000,00 untuk mencari harga jualnya, kemudian harga jual dikali dengan persentase upah yang diperoleh, sehingga diperoleh hasil yang sama. Agar lebih jelas, akan disajikan pembuktian subjek pada permasalahan pertama seperti Gambar 3.

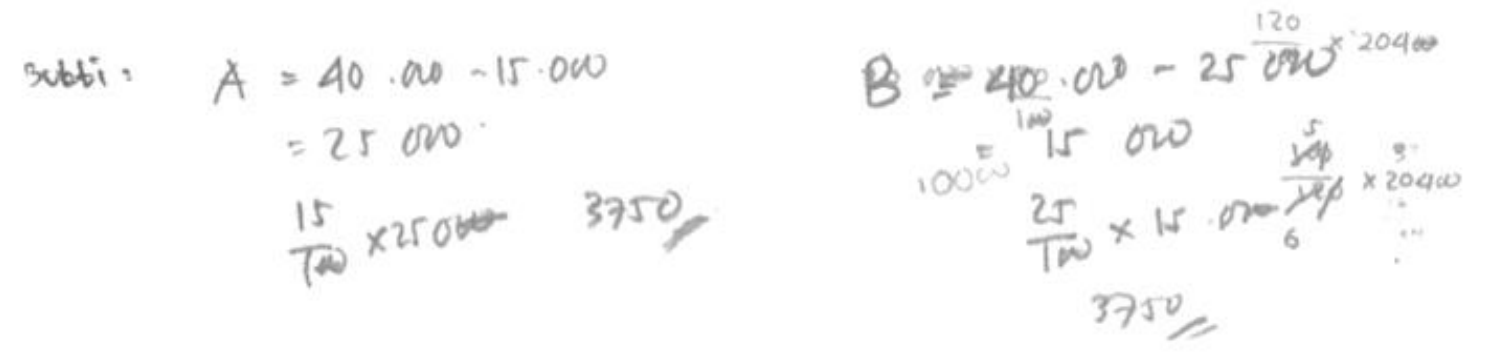

Gambar 3. Pembuktian subjek pada permasalahan pertama

Sedangkan permasalahan kedua, subjek meyakini bahwa proses pemecahan masalahnya salah, dikarenakan proses penyelesaian masalahnya tidak dapat diselesaikan sampai akhir. Walaupun demikian, subjek telah meyakini kebenaran hasil penyelesaian masalahnya dan dapat memberikan alasan yang tepat dan sesuai. Sehingga pada penelitian ini menunjukkan bahwa peserta didik dengan kecerdasan dominan musikal, logis matematis dan naturalistikmelakukan tahap pemeriksaan kembali dengan cara membuktikannya dan menjelaskan hal-hal yang penting pada langkah-langkahnya.

\section{Kecerdasan linguistik, interpersonal, dan kinestetis}

\section{Tahap Pemahaman Masalah}

Tahap ini, peserta didik mampu mengidentifikasikan masalah suatu soal, yaitu memahami masalah secara benar. Hal ini dapat diketahui pada Gambar 4.

\section{Label $=4$}

Gambar 4. Hasil tes tulis tahap pemahaman masalah

Berdasarkan hasil tes tulis pada tahap ini, subjek hanya menuliskan pemisalan pada hasil tes tulis untuk tahap pemahaman masalah pada permasalahan pertama. Subjek hanya menuliskan label $=\mathrm{x}$, sedangkan hal-hal yang diketahui pada masalah tersebut tidak dituliskan secara rinci. Kemudian pada permasalahan kedua, subjek tidak menuliskan apa 
yang diketahui. Hal ini dikarenakan subjek merasa malas dan telah terbiasa menyelesaikan permasalahan matematika tanpa harus menuliskan apa yang diketahui.

Walaupun penulisan terhadap apa yang diketahui subjek pada permasalah tidak disebutkan secara keseluruhan, namun dari hasil wawancara menunjukkan bahwa peserta didik telah melalui tahap pemahaman masalah. Hasil wawancara dari kedua permasalahan tersebut menyatakan bahwa peserta didik telah memahami masalah secara benar, walaupun tidak dituliskan dengan jelas. Subjek dapat menjelaskan apa yang telah dipahami dengan benar. Permasalahan pertama, subjek mengatakan apa yang diketahui pada permasalahan tersebut, sama seperti halnya pada permasalahan kedua. Sehingga berdasarkan hasil wawancara dan hasil tes tulis tersebut, dapat dikatakan bahwa subjek dengan kecerdasan dominan linguistik, interpersonal dan kinestetis telah melalui tahap pemahaman masalah dengan cara menyebutkan hal-hal yang diketahui pada permasalahan.

Walaupun penulisan terhadap apa yang diketahui subjek pada permasalah tidak disebutkan secara keseluruhan, namun dari hasil wawancara menunjukkan bahwa siswa telah melalui tahap pemahaman masalah. Lebih jelasnya, dijabarkan hasil wawancara tentang pemahaman subjek pada kedua soal sebagai berikut:

\section{Permasalahan pertama}

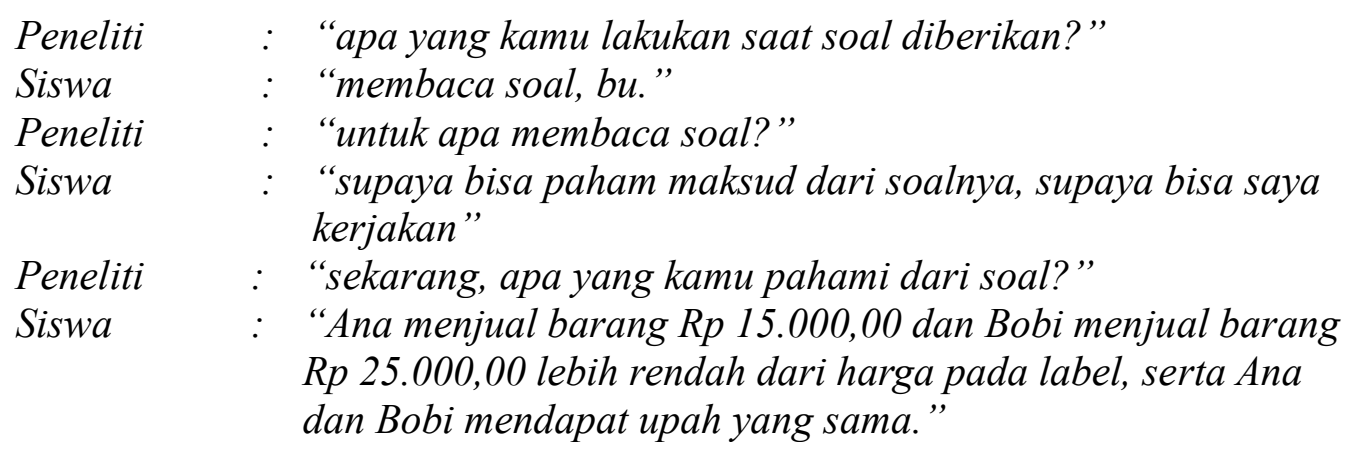

\section{Permasalahan kedua}

Siswa : "Pak Anto menjual dua mobil, kemudian memperoleh keuntungan $20 \%$ dan 10\%, serta harga jual kedua mobil sama."

Hasil wawancara dari kedua permasalahan tersebut menyatakan bahwa siswa telah memahami masalah secara benar, walaupun tidak dituliskan dengan jelas. Subjek dapat 
menjelaskan apa yang telah dipahami dengan benar. Permasalahan pertama, subjek mengatakan apa yang diketahui pada permasalahan tersebut, sama seperti halnya pada permasalahan kedua. Sehingga berdasarkan hasil wawancara dan hasil tes tulis tersebut, dapat dikatakan bahwa subjek dengan kecerdasan dominan linguistik, interpersonal dan kinestetis telah melalui tahap pemahaman masalah dengan cara menyebutkan hal-hal yang diketahui pada permasalahan.

\title{
Tahap Penyusunan Rencana
}

Tahap ini menunjukkan bahwa peserta didik mampu merencanakan penyelesaian masalahnya dengan menyusun dan menyatakan kembali permasalahan dengan menggunakan penalaran, variabel dan persamaan, menggunakan rumus atau sifat-sifat bilangan, mencoba menyederhanakan permasalahan dan menggunakan informasi yang diketahui untuk mengembangkan informasi baru.

Hasil penelitian menunjukkan bahwa subjek telah melalui tahap perencanaan penyelesaian. Hal ini diketahui dari wawancara sebagai berikut.

\author{
Permasalahan pertama \\ Peneliti : "bagaimana cara penyelesaian yang kamu ketahui?" \\ Siswa : "Saya misalkan harga label dengan x. dan saya menuliskan \\ persamaan, yaitu $x$ dikurangi dengan $R p$ 15.000,00 untuk \\ penjualan Ana dan x dikurangi dengan Rp 25.000,00 untuk \\ penjualan Bobi." \\ Peneliti : "setelah itu apa yang kamulakukan?" \\ Siswa : "saya mencari nilai x dengan mencoba-coba. Awalnya saya \\ mencoba x bernilai Rp 50.000,00, tapi hasilnya tidak sama, \\ kemudian saya mencoba $R p$ 40.000,00, ternyata hasilnya \\ sama. Sehingga saya peroleh hasilnya Rp 40.000,00.
}

\section{Permasalahan kedua}

Siswa : "yang terpikirkan adalah hanya mengurangi persen keuntungan dan kerugian dari kedua mobil. Karena hasilnya bernilai positif, sehingga Pak Anto mendapatkan keuntungan."

Hasil wawancara tersebut jelas menunjukkan bahwa subjek telah merencakan proses pemecahan masalah sebelumnya. Permasalahan pertama, subjek merumuskan persamaannya, kemudian diselesaikan. Subjek menggunakan strategi try and error untuk 
menyelesaikannya. Sedangkan pada permasalahan kedua, subjek hanya akan mengurangi persentase keuntungan dan kerugian mobil tersebut. Sehingga, wawancara tersebut menjelaskan solusi untuk menyelesaikan permasalahan tersebut. Subjek menjelaskan apa yang harus diselesaikan terlebih dahulu untuk memecahakan masalah tersebut.

Berdasarkan hasil wawancara, dapat dikatakan bahwa subjek dengan kecerdasan dominan linguistik, interpersonal dan kinestetismenyusun rencana dengan cara memisalkan dengan variabel, membuat persamaan, dan menyelesaikan dengan metodetry and error.

\section{Tahap Pelaksanaan Perencanaan Penyelesaian Masalah}

Tahap ini menunjukkan bahwa peserta didik mampu meyelesaikan masalah suatu soal sesuai dengan rencana. Hasil penelitian menunjukkan bahwa kedua peserta didik telah melakukan pelaksanaan perencenaan penyelesaian masalah. Hal ini dapat dilihat pada Gambar 5.

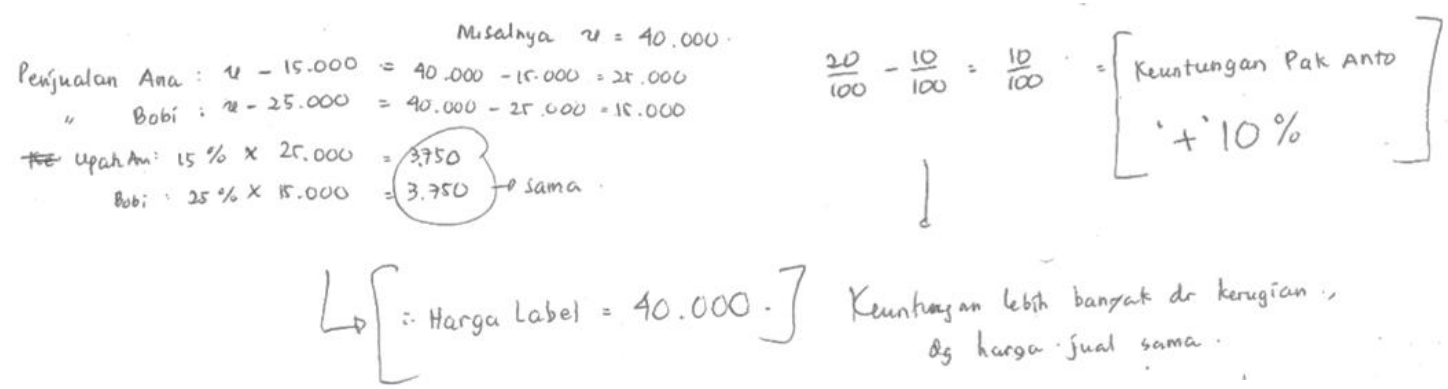

Gambar 5. Proses pemecahan masalah

Gambar 5 menunjukkan bahwa subjek melakukan proses pemecahan masalah sesuai dengan rencana yang dijelaskan melalui wawancara sebelumnya. Seperti pada permasalahan pertama, sebelumnya subjek menjelaskan bahwa subjek menyusun persamaannya, baru kemudian diselesaikan dengan try and error. Persamaan yang diperoleh dari harga label dikurangi dengan $\mathrm{Rp} 15.000,00$ dan $\mathrm{Rp} 25.000,00$. Setelah itu subjek mencari harga label dengan pemisalan. Jika upah Ana dan Bobi sama, maka itulah harga labelnya. Jadi, subjek mencari upah dengan mengalikan persentase dengan penjualan Ana dan Bobi. Selain itu, subjek menyelesaikan permasalahan kedua dengan mengurangi persentase keuntungan dan kerugian dari kedua mobil. Sehingga, perencanaan penyelesaian yang telah dijelaskan subjek melalui wawancara telah sesuai 
dengan yang dituliskan.

Berdasarkan proses pemecahan masalah yang ditulis subjek, dengan kecerdasan dominan linguistik, interpersonal dan kinestetis telah melalui tahap pelaksanaan perencanaan penyelesaian masalah dengan cara memisalkan sesuatu yang tidak diketahui dengan variabel, membuat persamaan dan menggunakan metode try and error.

\section{Tahap Pengecekan Kembali}

Tahap ini ditunjukkan dengan siswa mengecek kembali hasil yang diperoleh, dengan cara mengecek semua hal yang telah dilakukan apakah semua yang telah dilakukan dalam proses pemecahan masalah masuk akal untuk masalah pada soal tersebut atau tidak. Hasil penelitian untuk tahap ini dapat diketahui dari hasil wawancara berikut.

\section{Permasalahan pertama}

Peneliti : "yakin atau tidak dengan jawabannya ini?"

Siswa : "saya yakin jawaban saya benar bu."

Peneliti : "mengapa?"

Siswa : " "karena di situ kan sudah terbukti kalua harga labelnya $R p$ 40.000,00 berarti upah Ana dan Bobi sama."

\section{Permasalahan kedua}

$\begin{array}{lll}\text { Peneliti } & : & \text { "yakin atau tidak dengan jawabannya ini?" } \\ \text { Siswa } & : & \text { "saya tidak tahu benar atau tidak bu." } \\ \text { Peneliti } & : & \text { "mengapa?" } \\ \text { Siswa } & : \text { "karena sebenarnya saya tidak tau pasti cara untuk } \\ & \text { menyelesaikannya, namun yang terpikirkan hanya cara ini, } \\ & \text { jadi saya menggunakan cara ini dan saya juga tidak dapat } \\ & \text { membuktikannya." }\end{array}$

Hasil wawancara tersebut menunjukkan bahwa subjek masih belum yakin terhadap proses pemecahan masalahnya. Permasalahan pertama, subjek meyakini bahwa proses penyelesaian masalahnya benar. Subjek meyakini hasil akhirnya karena menurut subjek bahwa apa yang dikerjakan telah terbukti. Sedangkan permasalahan kedua, subjek tidak yakin terhadap proses pemecahan masalahnya apakah salah atau tidak. Hal ini dikarenakan subjek tidak mengetahui pasti cara untuk menyelesaikannya. Berdasarkan hasil wawancara ini, dapat dikatakan bahwa proses memeriksa kembali pada siswa dengan kecerdasan dominan linguistik, interpersonal dan kinestetis tidakada dalam tahap 
pemecahan masalah Polya.

\section{Kecerdasan eksistensial, intrapersonal, dan visual}

\section{Tahap Pemahaman Masalah}

Tahap ini, peserta didik mampu mengidentifikasikan masalah suatu soal, yaitu memahami masalah secara benar, seperti tampak pada Gambar 6.

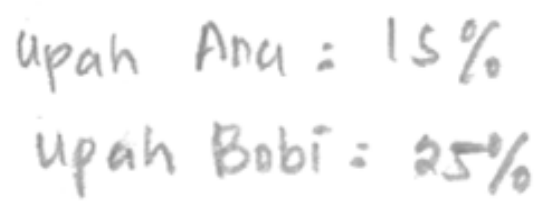

Gambar 6. Hasil tes tulis tahap pemecahan masalah

Subjek menjelaskan apa yang dipahami dari permasalahan pada wawancara. Subjek menjelaskan permasalahan yang terdapat pada soal. Selain itu, subjek juga menuliskan hal-hal yang diketahui pada proses pemahaman masalah, namun tidak lengkap. Berdasarkan hasil wawancara tersebut, dapat dikatakan bahwa subjek dengan kecerdasan dominan eksistensial, intrapersonal dan visual telah melalui tahap pemahaman masalah dengan cara menyebutkan apa saja yang diketahui pada permasalahan, tetapi yang diketahui tidak semua disebutkan dan menyebutkan apa yang ditanya pada permasalahan. Untuk detailnya, bisa dilihat pada hasil wawancara berikut ini:

\section{Permasalahan pertama}

Peneliti : "apa yang kamu lakukan saat soal diberikan?”

Siswa : "saya membaca soal"

Peneliti : "kamu membaca soal untuk apa?"

Siswa : "supayabisa memahami permasalahan yang pada soal."

Peneliti : "permasalahan apa yang kamu dapat pada soal?"

Siswa : "harga label dari Ana dan Bobi dengan upahnya yang sama"

Permasalahan kedua

Siswa : "permasalahannya yaitu mencari persentase keuntungan atau kerugian pak Anto."

Peneliti : "apa yang kamu tau selain permasalahan tersebut pada soal?"

Siswa : "penjualan mobil pertama untung 20\% dan penjualan mobil kedua rugi $10 \% "$ 


\section{Tahap Penyusunan Rencana}

Tahap ini menunjukkan bahwa peserta didik mampu merencanakan penyelesaian masalahnya dengan menyusun dan menyatakan kembali permasalahan dengan menggunakan penalaran, variabel dan persamaan, menggunakan rumus atau sifat-sifat bilangan, mencoba menyederhanakan permasalahan dan menggunakan informasi yang diketahui untuk mengembangkan informasi baru.

Hasil penelitian menunjukkan bahwa subjek telah melalui tahap perencanaan penyelesaian. Hal ini diketahui dari wawancara sebagai berikut.

\section{Permasalahan pertama}

Peneliti : "bagaimana cara penyelesaian yang kamu ketahui?"

Siswa : "saya kalikan persen upah keduanya dengan harga label yang dikurangi dengan Rp 15.000,00 dan Rp 25.000,00 pada persamaan."

\section{Permasalahan kedua}

\begin{tabular}{|c|c|}
\hline Siswa & $\begin{array}{l}\text { "harga jual mobil pertama ditambah persen keuntungannya } \\
\text { dikali harga jual mobil pertama. Kemudian saya kurangi } \\
\text { harga jual mobil kedua dengan persen kerugian dikali harga } \\
\text { jual mobil kedua." }\end{array}$ \\
\hline Peneliti & $\begin{array}{l}: \text { "mengapa harga jual mobil pertama ditambah, sedangkan } \\
\text { harga jual mobil kedua dikurangi?"” }\end{array}$ \\
\hline Siswa & $\begin{array}{l}\text { : "karena mobil pertama adalah persen keuntungan sehingga } \\
\text { saya jumlahkan, dan mobil kedua adalah persen kerugiannya, } \\
\text { sehingga saya kurangi." }\end{array}$ \\
\hline
\end{tabular}

Hasil wawancara tersebut jelas menunjukkan bahwa subjek telah merencakan proses pemecahan masalah sebelumnya. Permasalahan pertama dan kedua pada wawancara tersebut, subjek menjelaskan solusi untuk menyelesaikan permasalahan tersebut. Subjek menjelaskan bagaimana cara memecahakan masalah tersebut. Permasalahan pertama, subjek menjelaskan bahwa persentase upah keduanya dikali dengan harga pada label yang dikurangi dengan $\mathrm{Rp}$ 15.000,00 dan Rp 25.000,00. Sedangkan pada permasalahan kedua, subjek menambahkan persentase keuntungan yang dikali harga jual dengan harga jualnya, begitu pula untuk mobil kedua. Namun, untuk mobil yang mengalami kerugian, subjek mengurangi persentase kerugian yang dikali harga jual dengan harga jualnya. Berdasarkan hasil wawancara, dapat dikatakan bahwa siswa dengan kecerdasan dominan eksistensial, intrapersonal dan visual telah melalui 
tahap penyusunan rencana penyelesaian dengan cara membuat persamaan terlebih dahulu, setelah itu diselesaikan dengan menggunakan persamaan tersebut.

\section{Tahap Melaksanakan Rencana}

Tahap ini menunjukkan bahwa peserta didik mampu meyelesaikan masalah suatu soal sesuai dengan rencana. Hasil penelitian menunjukkan bahwa kedua peserta didik telah melakukan pelaksanaan perencenaan penyelesaian masalah. Hal ini dapat dilihat pada Gambar 7.
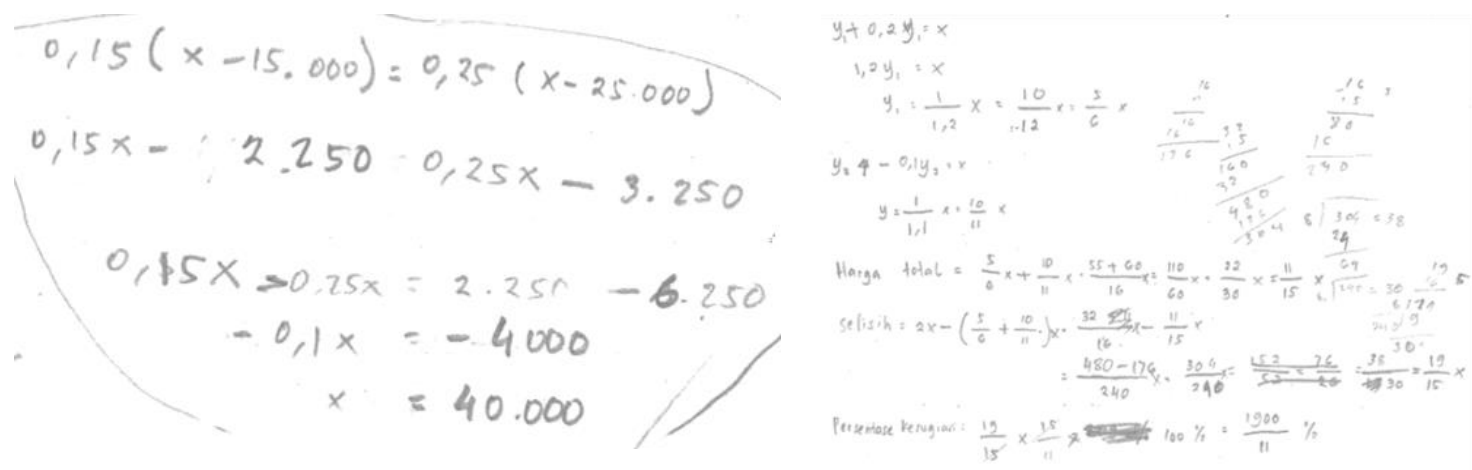

Gambar 7. Proses pemecahan masalah

Gambar 7 menunjukkan bahwa subjek melakukan proses pemecahan masalah sesuai dengan rencana yang dijelaskan melalui wawancara sebelumnya. Seperti pada permasalahan pertama, sebelumnya subjek menjelaskan bahwa persentase upah keduanya dikali dengan harga pada label yang dikurangi dengan Rp 15.000,00 dan Rp 25.000,00. Subjek memisalkan harga pada label dengan $\mathrm{x}$. karena upah keduanya sama, maka subjek menggunakan tanda sama dengan diantara penjualan Ana dan Bobi sehingga diperoleh hasil akhirnya.

Persamaan kedua, diperoleh dari menambahkan persentase keuntungan yang dikali harga jual dengan harga jualnya, begitu pula untuk mobil kedua. karena mobil kedua mengalami kerugian, maka subjek mengurangi persentase kerugian yang dikali harga jual dengan harga jualnya. Berdasarkan hasil wawancara pada tahap perencanaan, maka hasilnya sama dengan proses pemecahan masalah subjek pada tahap ini. Sehingga, dapat dikatakan bahwa subjek dengan kecerdasan dominan eksistensial, intrapersonal dan visual telah melalui tahap pelaksanaan perencanaan penyelesaian masalah dengan cara 
memisalkan sesuatu dengan variabel dan membuat persamaan.

\section{Tahap Memeriksa Kembali}

Tahap ini ditunjukkan dengan siswa mengecek kembali hasil yang diperoleh, dengan cara mengecek semua hal yang telah dilakukan apakah semua yang telah dilakukan dalam proses pemecahan masalah masuk akal untuk masalah pada soal tersebut atau tidak. Hasil penelitian untuk tahap ini dapat diketahui dari hasil wawancara berikut.

\section{Permasalahan pertama}

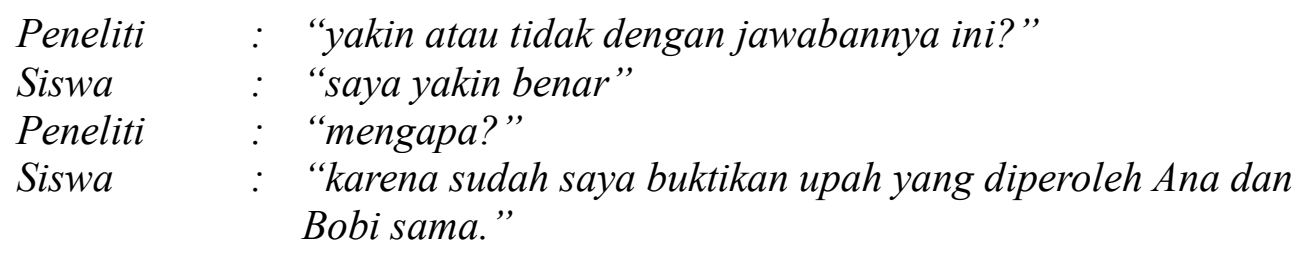

\section{Permasalahan kedua}

$$
\begin{array}{ll}
\text { Peneliti } & : \text { "yakin atau tidak dengan jawabannya ini?" } \\
\text { Siswa } & : \text { "saya yakin benar" } \\
\text { Peneliti } & : \text { "mengapa?" } \\
\text { Siswa } & : \text { "karena untuk mencari persentase keuntungan atau kerugian } \\
& \text { pak Anto, yaitu dengan membagikan selisih harga jual dan } \\
& \text { harga total dari kedua mobil Pak Anto dikali 100\%, dan } \\
& \text { sudah saya kerjakan seperti itu." }
\end{array}
$$

Hasil wawancara tersebut menunjukkan bahwa subjek telah dapat mengetahui alasan dari apa yang ditulis, serta terdapat keyakinan terhadap jawabannya dan dapat dibuktikan. Subjek dapat menjelaskan tentang apa saja yang ditulis. Permasalahan pertama, subjek meyakini bahwa proses penyelesaian masalahnya benar sampai akhir. Subjek yakin hasil akhirnya telah dibuktikan. Sedangkan pada permasalahan kedua, subjek meyakini bahwa jawabannya benar karena untuk mencari persentase keuntungan atau kerugian pak Anto, yaitu dengan membagikan selisih harga jual dan harga total dari kedua mobil Pak Anto dikali $100 \%$. Sehingga pada penelitian ini menunjukkan bahwa siswa dengan kecerdasan dominan eksistensial, intrapersonal dan visual juga memiliki tahap memeriksa kembali pada proses pemecahan masalah Polya dengan pembuktian dan dapat dipertanggungjawabkan.

Hasil penelitian yang telah dipaparkan sebelumnya menunjukkan bahwa setiap 
peserta didik mempunyai proses pemecahan yang hampir sama untuk kecerdasan domain majemuk yang berbeda-beda, sehingga sebagai tolak ukur tingkat berpikir setiap peserta didik tidak dapat dilihat hanya dari satu aspek saja (Putra \& Sumadi, 2018). Serta masih terdapat beberapa kesulitan dalam menyelesaikan masalah matematika (In'am, 2015). Sehingga untuk meningkatkan pemecahan masalah matematika pada peserta didik perlu memperhatikan kecerdasan majemuk peserta didik (Rahbarnia, Hamedian, \& Radmehr, 2014). Sesuai dengan penelitian terdahulu yang menyatakan bahwa langkah untuk menyelesaikan suatu masalah matematika berbeda pada beberapa peserta didik yang memiliki kecerdasan majemuk yang berbeda, karena perbedaan kecerdasan majemuk mempengaruhi setiap peserta didik dalam memahami materi (Rohmatin \& Rahmawati, 2013).

Pemahaman masalah oleh peserta didik dengan kecerdasan dominan musikal, logis matematis dan naturalistik dilakukan dengan cara menuliskan apa yang diketahui, walaupun penulisannya tidak lengkap. Hal ini sesuai dengan penelitian terdahulu In'am (2015) yang menyatakan bahwa salah satu kesulitan peserta didik dalam menyelesaikan masalah matematika adalah kesalahan menulis atau menghitung. Subjek juga menyusun rencana dalam menyelesaikan masalah dengan cara memisalkan hal yang ditanya dengan variabel dan membuat persamaan hal itu sesuai dengan pelaksanaan rencana yang dilakukan. Selain itu, subjek melakukan tahap pemeriksaan kembali dengan cara membuktikannya dan menjelaskan hal-hal yang penting pada langkah-langkahnya.

Sehingga peserta didik dengan kecerdasan dominan musikal, logis matematis dan naturalistik memecahkan masalah matematika dengan cara menjelaskan hal-hal yang diketahui dan ditanya pada permasalahan kemudian membuat persamaan dan menggunakan metode substitusi. Hal ini sesuai dengan penelitian terdahulu In'am (2012) yang menyatakan bahwa peserta didik dalam memecahkan masalah matematika menggunakan langkah-langkah mengidentifikasi sesuatu yang diketahui dan ditanya dalam masalah, memilih rumus yang berkaitan dengan sesuatu yang diketahui dan ditanya dalam masalah, serta mensubtitusi sesuatu yang diketahui ke dalam rumus untuk memperoleh pemecahan masalah.

Peserta didik dengan kecerdasan dominan musikal, logika matematika dan natural pada penelitian ini juga telah melalui keempat tahap Pemecahan Masalah Polya. Hal ini sesuai dengan hasil penelitian Rohmatin dan Rahmawati (2013) yang menyatakan bahwa 
peserta didik dengan kecerdasan ini telah dapat membangun makna tentang masalah apa yang akan dipecahkan, dilakukan dengan mermuskan kembali; memutuskan strategi yang akan dipakai untuk memecahkan masalah; menerapkan strategi yang telah dipilih; mengecek semua hal yang telah dilakukan, dari alasan, rangkaian alasan sampai pada kesimpulan untuk memeriksa jawaban, apakah semuanya masuk akal untuk masalah tersebut.

Selain itu, Rahbarnia, Hamedian, dan Radmehr (2014) juga menyatakan bahwa tahap pemahaman masalah peserta didik yang memiliki kecerdasan dominan logika matematika dan natural adalah memahami, menerapkan dan menganalisis masalah. Nelson (1998) menjelaskan bahwa kecerdasan logika matematika merupakan potensi untuk memahami sebab dan efek untuk memanipulasi angka, jumlah dan operasi, serta kecerdasan musikal merupakan potensi untuk mengenali dan mengingat pola. Sehingga kecerdasan ini kebanyakan dapat digunakan untuk menganalisis dan menggabungkan data dalam skema (McKanzie, 2005).

Pemahaman masalah peserta didik dengan kecerdasan dominan linguistik, interpersonal dan kinestetis dilakukan dengan cara menyebutkan hal-hal yang diketahui pada permasalahan. Proses penyusunan rencana dan pelaksanaan rencana dilakukan dengan cara memisalkan sesuatu yang tidak diketahui dengan menggunakan variabel, membuat persamaan dan menggunakan metode try and error. Hal ini sesuai dengan penelitian terdahulu yang menyatakan bahwa peserta didik dalam memecahkan masalah matematika menggunakan langkah-langkah mengidentifikasi sesuatu yang diketahui dan ditanya dalam masalah, memilih rumus yang berkaitan dengan sesuatu yang diketahui dan ditanya dalam masalah, serta mensubtitusi sesuatu yang diketahui ke dalam rumus untuk memperoleh pemecahan masalah (In'am, 2012).

Peserta didik dengan kecerdasan dominan linguistik, interpersonal dan kinestetis pada penelitian ini melalui tiga tahap Pemecahan Masalah Polya. Hal ini bertolak belakang dengan hasil penelitian Rohmatin dan Rahmawati (2013) yang menyatakan bahwa peserta didik dengan kecerdasan ini telah dapat membangun makna tentang masalah apa yang akan dipecahkan, dilakukan dengan merumuskan kembali; memutuskan strategi yang akan dipakai untuk memecahkan masalah; menerapkan strategi yang telah dipilih; mengecek semua hal yang telah dilakukan, dari alasan, rangkaian alasan sampai pada kesimpulan untuk memeriksa jawaban, apakah semuanya 
masuk akal untuk masalah tersebut. Namun, dalam penelitian ini pada tahap penerapan strategi, peserta didik tidak dapat menjelaskan dengan pasti alasan dari proses pemecahan masalah yang ditulisnya sehingga tidak terdapat keyakinan pada diri peserta didik terhadap hasil pemecahan masalahnya.

Rahbarnia, Hamedian, dan Radmehr (2014) juga menyatakan bahwa tahap pemahaman masalah peserta didik yang memiliki kecerdasan dominan ini hanya pada tahap penerapan tujuan. Hal ini diperkuat oleh Nelson (1998), yang menyatakan bahwa kecerdasan interpersonal merupakan potensi untuk bekerja dengan orang lain, sehingga diperlukan kerja sama untuk memecahkan suatu masalah matematika. Kecerdasan ini diperoleh melalui proses sosial yang terbangun secara alamiah (McKanzie, 2005).

Pemahaman masalah peserta didik dengan kecerdasan dominan linguistik, interpersonal dan kinestetis dilakukan dengan cara menyebutkan apa yang diketahui dan ditanya yang terdapat permasalah, namun yang disebutkan tidak lengkap. Tahap penyusunan rencananya dengan cara membuat persamaan untuk menyelesaikan permasalahan. Tahap pelaksanaan rencana dilakukan dengan cara memisalkan hal yang ditanya dengan variabel dan membuat persamaan. Tahap memeriksa kembali dilakukan dengan melakukan pembuktian.

Peserta didik dengan kecerdasan dominan eksistensial, intrapersonal dan visual pada penelitian ini telah melalui keempat tahap Pemecahan Masalah Polya. Hal ini sesuai dengan hasil penelitian Rohmatin dan Rahmawati (2013) yang menyatakan bahwa peserta didik dengan kecerdasan ini telah dapat membangun makna tentang masalah apa yang akan dipecahkan, dilakukan dengan mermuskan kembali; memutuskan strategi yang akan dipakai untuk memecahkan masalah; menerapkan strategi yang telah dipilih; mengecek semua hal yang telah dilakukan, dari alasan, rangkaian alasan sampai pada kesimpulan untuk memeriksa jawaban, apakah semuanya masuk akal untuk masalah tersebut. Hal ini didasari pada pendapat McKanzie (2005), yang menyatakan bahwa peserta didik yang memiliki kecerdasan ini mempunyai keyakinan terhadap pembelajaran baru.

\section{KESIMPULAN}

Peserta didik dengan kecerdasan dominan musikal, logis matematis dan naturalistik yaitu pemahaman masalah, menyelesaikan suatu permasalahan matematika dengan mengidentifikasi hal-hal yang diketahui, menggunakan variabel, membuat persamaan dan 
memakai metode substitusi dalam penyelesaiaannya. Selanjutnya, peserta didik dengan kecerdasan ini mengoreksi proses pemecahan masalahnya dengan membuktikan hal-hal yang telah diperoleh. Peserta didik dengan kecerdasan dominan linguistik, interpersonal dan kinestetis menyelesaikan suatu permasalahan matematika dengan mengidentifikasi hal-hal yang diketahui, menggunakan variabel, membuat persamaan, namun, tidak melakukan tahap mengoreksi kembali. Terakhir, peserta didik dengan kecerdasan dominan eksistensial, intrapersonal dan visual menyelesaikan suatu permasalahan matematika dengan cara mengidentifikasikan hal-hal yang diketahu, namun tidak lengkap, menggunakan variabel dan persamaan untuk menyelesaikan permasalahan.

\section{DAFTAR RUJUKAN}

Aliyah, U.H., Suyitno, H., \& Agoestanto, A. (2014). Keefektifan Resource Based Learning terhadap Kemampuan Pemecahan Masalah Peserta Didik Materi Lingkaran. Jurnal Pendidikan Matematika dan Sains, 2(1), 10-18.

Anggo, M. (2014). Metakognisi dan Usaha Mengatasi Kesulitan dalam Memecahkan Masalah Matematika Kontekstual. AKSIOMA, 1(1), 21-28.

Anikrohmah, Mubarokah, L., \& Suhartatik. (2013). Identifikasi Strategi Pemecahan Masalah Matematika Luas Permukaan dan Volume Balok pada Peserta Didik. Jurnal Pendidikan Matematika STIKIP PGRI Sidoarjo, 1(2), 11-20.

Arifah, U., \& Saefudin, A. A. (2017). Menumbuhkembangkan kemampuan pemahaman konsep matematika dengan menggunakan model pembelajaran guided discovery. Union: Jurnal Pendidikan Matematik, 5(3), 263-272.

Gardner, H. (2003). Terjemahan: Multiple Intelligences (Kecerdasan Majemuk - Teori dalam praktek. Husna, Ikhsan, M., Fatimah, S. Batam: Interaksara. (2013).

In'am, A. (2012). A Metacognitive Approach to Solving AlgebraProblems. International Journal of Independent Research and Strudies, 1(4), 162-173.

In'am, A. (2015). Menguak Penyelesaian Masalah Matematika (Analisis Pendekatan Metakognitif dan Model Polya. Malang: Aditya Media.

Kurniawan, D. (2014). Analisis Kesulitan Perkuliahan Fisika Dasar dan Profil Kecerdasan Majemuk Mahapeserta didik Calon Guru Matematika Tingkat I FKIP Unswagati Cirebon. Jurnal Euclid, 1(2), 93-104.

McKenzie, W. (2005). Multiple Intelligences and Instructional Technology. Washington, DC: International Society for Technology in Education.

Muslihun \& Hildayani, S. Z. (2015). SUJU: Sukses Juara Olimpiade Matematika SMA/MA Nasional dan Internasional. Jakarta: Grasindo. 
Nelson, K. (1998). Developing Students' Multiple Intelligences. New York: Scholastic.

Nurasyiyah, D.A. (2014). Pendekatan Metakognitif dalam Pembelajaran Matematika untuk Pencapaian Kemampuan Koneksi dan Pemecahan Masalah Matematik Peserta didik SMA. JMP, 6(2), 115-125.

Polya, G. (1973). How to Solve It - A New Aspect of Mathematical Method. United States of America: Princeton University Press.

Putra, Y.P., \& Sumadi, S. (2018). Pelatihan Pengembangan Pembelajaran Bahasa dan Matematika Dasar Berbasis Multiple Intelligence Anak Usia Dini Bagi Guru Paud Alam Mentari Kabupaten Sorong. Jurnal Abdimasa, 1(1), 38-41.

Putri, Y. B. (2016). Model Pembelajaran Investigasi Kelompok dan Kemampuan Pemecahan Masalah Siswa dalam Pembelajaran Matematika. Prosiding Seminar Nasional Matematika IX 2015, Semarang, (pp. 44-49).

Rahbarnia, F., Hamedian, S., \& Radmehr, F. (2014). A Study on the relationship between multiple Intelligences and mathematical problem solving based on Revised Bloom Taxonomy. Journal of Interdisciplinary Mathematics, 17(2), 109-134.

Rohmatin, D. N. \& Rahmawati, A. (2013). Profil Berpikir Kritis Peserta didik SMP dalam Memecahkan Masalah Matematika Ditinjau dari Kecerdasan Majemuk sebagai Upaya Dasar Menentukan Strategi Pembelajaran. Indonesian Science \& Technology Digital Library. elib.pdii.lipi.go.id.

Rusyida, W. Y., Asikin, M., \& Soedjoko E. (2013). Komparasi Model Pembelajaran CTL dan MEA terhadap Kemampuan Pemecahan Masalah Materi Lingkaran. Unnes Journal of Mathematics Education, 2(1), 1-7.

Santoso, N., Waluyo, S.B., \& Sukestiyarno. (2013). Kemampuan Pemecahan Masalah pada Pembelajaran Matematika dengan Strategi Master dan Penerapan Scaffolding. Unnes Journal of Mathematics Education Research, 2(2), 69-75.

Setyadi, D. (2018). Proses Metakognisi Mahapeserta didik dalam Memecahkan Masalah Matematika (Studi Kasus Pada Mahapeserta didik Pendidikan Matematika UKSW). Kreano: Jurnal Matematika Kreatif - Inovatif, 9(1), 93-99.

Sweller, J. (1988). Cognitive Load During Problem Solving: Effects on Learning. Cognitive Science, 12, 257-258.

Wicaksono, D. P., dkk. (2014). Pengembangan Perangkat Pembelajaran Matematika Berbahada Inggris Berdasarkan Teori Kecerdasan Majemuk pada Materi Balok dan Kubus untuk Kelas VIII SMP. Jurnal Elektronik Pembelajaran Matematika, 2(5), 534-549.

Yaumi, M., \& Ibrahim, N. (2013). Pembelajaran Berbasis Kecerdasan Jamak (Multiple Intelligences) - mengidentifikasi dan mengembangkan multitalenta anak. Jakarta: Kencana. 